\title{
SIR WATKIN WILLIAMS WYNN AND THE RUTGERS HANDEL COLLECTION*
}

\author{
BY MARTIN PICKER
}

Dr. Picker is a musicologist and Professor of Music at Rutgers, The State University of New Jersey, in New Brunswick.

A chance visit in January, 1991, to the National Museum of Wales in Cardiff drew my attention to a portrait in their collection of the young Sir Watkin Williams Wynn (1749-89) painted on a visit he made to Italy in 1768. (Pl. 1) I had previously encountered his name as that of an enthusiast and collector of art and music, particularly music by Handel, some of which had found its way into Special Collections and Archives of the Rutgers University Libraries in New Brunswick, New Jersey. That visit has led me to the present attempt to explore Sir Watkin's relationship to art and music, and especially to Handel and the Handel collection at Rutgers.

In the December 1965 issue of this Joumal I described a collection of prints and manuscripts of music by George Frideric Handel housed in Special Collections and Archives of the Alexander Library of Rutgers in New Brunswick. ${ }^{1}$ It was explained there that part of the collection was acquired by Rutgers around 1950 as a result of a purchase by the Dana Library of Rutgers in Newark that had been recommended by Professor Alfred Mann, a distinguished Handel scholar, now emeritus.

Some time after this purchase, which included eleven manuscript volumes described in my article cited above, the materials were transferred to Special Collections in New Brunswick. At that time the provenance of the Handel manuscripts was largely a mystery, although it is clear that they were once part of a single collection, being uniformly bound in leather and numbered consecutively from I to IX, lacking vol. IV but including an "Appendix Vol. I" and two unnumbered volumes. ${ }^{2}$ All the numbered volumes are devoted to Anthems, while the unnumbered ones contain An Ode for Queen Anne's Birthday and Italian Duettos and Trios. ${ }^{3}$ Since the publication of my article, the collection, and particularly the manuscripts, have been cited in the relevant literature, including studies by Larsen, Dean, and Beeks, the Handel thematic catalogue by Baselt, and the edition of Anthems in the Hallische Händel-Ausgabe. ${ }^{4}$ 
In 1975 , nearly ten years after publishing my article, I received a letter from Graydon F. Beeks, Jr., who was then engaged in research for his doctoral dissertation on Handel's Chandos Anthems. He pointed out to me that Charles Burney, in An Account of the Musical Performance in WestminsterAbbey and the Pantheon . . 1784 in Commemoration of Handel (London, 1785), after providing a summary list of Handel's works, described some private collections of music by Handel, including that of Sir Watkin Williams Wynn. (Pl. 2) Burney's descriptions correspond exactly to six of the eleven volumes of the Rutgers collection, as follows:

Sir Watkin William Wynn, besides the printed OPERAS, ORATORIOS, and TE DEUMS, of HANDEL, is in possession of the following Manuscript Scores: TE DEUM in A, and the ANTHEM, "Let God arise," both transposed and altered, for the King's Chapel. "I will magnify thee," compiled and altered, from several Anthems, for the Sons of the Clergy, at St. Paul's. (= Appendix Vol. I; see Pl. 3)

"As pants the hart," for five voices; with several alterations and additions, by HANDEL himself, when it was introduced in the Oratorio of ESTHER. (= Vol. VI)

"The king shall rejoice." Performed at the Chapel-Royal, on the victory obtained at Dettingen. "Sing unto God." Performed at the nuptials of their late Royal Highnesses, the prince and princess of Wales, 1736. ( = Vol. VII) "Blessed are they": partly composed, and partly compiled, for the Foundling Hospital. ( = Vol. VIII)

"Let God arise," "As pants the hart." Adapted to voices, without instruments, for the Chapel Royal. ( = Vol. IX)

ODE, or SERENATA, composed for the birth-day of queen Anne. ( = Vol. $\mathrm{X})^{5}$

Because of the virtual identity of Burney's descriptions, including the order in which he lists the MSS, to volumes in the Rutgers collection, it is highly probable that he is describing these very ones. Their uniformity of binding and the appearance of the same copyists's hands in more than one volume strongly suggest that most if not all were in Wynn's possession in 1784. It is not possible to say which of the "printed Operas, Oratorios, and Te Deums" in the Wynn collection may be represented at Rutgers, but it is likely that Rutgers possesses a substantial nucleus of its Handel material. Beeks refers to his identification of the Wynn collection at Rutgers in his 1981 Berkeley dissertation and his article of the same year on the Chandos Anthems. ${ }^{6}$ 
Despite the welcome information from Dr. Beeks about the Wynn collection, I did not pursue the matter until last year, when I mounted an exhibit of early manuscript and printed music at the Alexander Library in New Brunswick. This exhibit included a number of items from the Wynn Handel collection, among them two volumes of Anthems (Appendix Vol. I and Vol. IX) and the Birthday Ode (Vol. X). I found it pertinent to mention Wynn's role in forming the collection in the catalogue of the exhibit. ${ }^{7} \mathrm{I}$ also decided to learn more about Sir Watkin Williams Wynn. My chance visit to Cardiff confirmed my decision, resulting in the present essay.

Who was Sir Watkin Williams Wynn? The Dictionary of Welsh Biography (1959) informs us that the Wynn family of Wynnstay, Ruabon (Denbighshire), have been prominent Welsh landowners distinguished in local and national affairs from the seventeenth century to the present. ${ }^{8}$ The first Sir Watkin Williams (1692-1749) adopted the family name Wynn from his mother's side after succeeding to the Wynnstay estate in 1740 . His son, Sir Watkin Williams Wynn II (1749-89), is chiefly remembered as a patron of the arts, and it was he who owned the Rutgers Handel MSS described by Burney.

The younger Watkin Williams Wynn's interest in music was probably kindled in his youth and manifested itself when he was still in his teens, by the time of the portrait in Cardiff (see Pl. 1). In 1776, at the age of twentyseven, he was a member of a committee of noblemen in London that established "The Concert of Ancient Music," a society specifically dedicated to the performance of music written more than twenty years previously (mainly by Handel), and in 1783 he was, with Viscount Fitzwilliam and Joah Bates, an organizer of the Handel Commemoration which took place in London the following year, and of which he was one of the Directors. ${ }^{9}$ He was a patron and amateur of both art and music, counting such artists as Reynolds and Sandby among his friends, and he commissioned paintings by Batoni, Reynolds, Mengs, and others. ${ }^{10}$

His patronage of music is reflected not only in his collection of Handel manuscripts and his role in the "Ancient Concerts" society and Commemoration, but in the fact that he had the Welsh harpist John Parry (c.1710-82) in his employ, as had his father before him. ${ }^{11}$ Handel is said to have been an admirer of Parry, and thus may have been acquainted with the elder Wynn. ${ }^{12}$

Whatever may have been the connection between Handel and the Wynn family, it is known that Parry, the most distinguished British harpist of his time, played a concerto by Handel (probably the Harp Concerto in B-flat, Op. 4, No. 6) in London in $1741 .{ }^{13}$ Parry was also a composer of music for 
harp and guitar, and he arranged traditional Welsh airs for the harp, publishing three books of such arrangements in the course of his life $(1742,1761$, 1781). ${ }^{14}$

Sir Watkin Williams Wynn had been associated with the distinguished musician and music historian Dr. Charles Burney as early as 1774 , when Burney tried, unsuccessfully, to persuade the Governors of the Foundling Hospital in London (with which Handel had also been associated, and for which he wrote the anthem contained in vol. VIII of the Wynn Handel MSS) to transform it into a Conservatory of Music along the lines of an Italian Conservatorio. Burney's proposal led the Court of Governors to appoint a Special Committee "to digest and form the properest method for carrying the said plan into execution." 15 Sir Watkin, then but twenty-five years old, was one of five gentlemen appointed to join with members of the Court in drawing up recommendations. Only two weeks later, however, the Court decided to reject the scheme on the grounds that the Act of Parliament establishing the Hospital did not allow for such a change.

In a few commissions we find Sir Watkin's artistic and musical interests intertwined. The most interesting case is the decoration of the Music Room of his London residence, designed by Robert Adam in 1773. Adam's plan describes the panels on either side of the fireplace "for pictures of St. Cecilia etc.," and the doors of the organ cabinet were "to have Heads of great Musicians." Over the entrance door were to be "the Muses that honour the Tomb of Orpheus," and elsewhere were to be ornamental lyres. A painting of Orpheus by Nathaniel Dance was placed to the left of the fireplace, and one of St. Cecilia playing a harp (clearly a reference to a traditional Welsh instrument) by Sir Joshua Reynolds (dated 1775) to the right. ${ }^{16}$

Another manifestation of Wynn's musical interests is contained in a triple portrait, or "conversation piece," painted in 1768-72 by Pompeo Batoni, one of the leading Italian portrait painters of the late eighteenth century. (This is the painting in Cardiff that prompted this essay; see Pl. 1). At the age of nineteen, after completing his education at Oxford, Wynn was sent by his mother on the "Grand Tour," considered essential for every well-born young Briton. He was accompanied by two companions, Captain Edward Hamilton and Thomas Apperley, the latter an older friend from Oxford and possibly his tutor. On arriving in Rome in 1768, Wynn engaged a musicmaster, purchased music and antiquities, arranged for private concerts, and ordered a life-sized portrait from Batoni of himself and his companions. ${ }^{17}$ In this life-size painting Sir Watkin stands on the left, holding a crayon and a drawing, evidently from his own hand, that has been identified as a copy of 
one of Raphael's frescoes in the Vatican palace. His soft features display his youth, and his paunch foreshadows his eventual corpulence. On the right is Captain Hamilton holding a flute, representing an interest in music that he evidently shared with Sir Watkin. The seated figure in the center is Apperley with a volume of Dante before him, which he appears to be explicating. ${ }^{18}$

Other Wynn portraits include a caricature by Thomas Patch made in Florence in 1768, at about the same time as Batoni's portrait. A version of it, undoubtedly exaggerated for humorous effect, shows a beefy, short-necked Sir Watkin with enormous jowls and a projecting lower lip. ${ }^{19}$ A more flattering and probably accurate representation is a terracotta bust by Christopher Hewetson of 1769 , recognizable as the young patrician in Batoni's painting. ${ }^{20}$

A drawing by the landscape painter Paul Sandby of Sir Watkin sketching (1777) offers persuasive evidence of the latter's artistic aspirations. Sandby had given Wynn lessons in drawing in 1770, and together they made several tours of Wales for the purpose of sketching the countryside. ${ }^{21}$ Most interesting is a group portrait by Sir Joshua Reynolds of "A Meeting of the Society of Dilettanti" (1777-79) which shows Sir Watkin, seated on the left, presiding while most of the others raise their glasses in a toast to a new member, and one, with a sly smile, holds up a lady's garter in his left hand. ${ }^{22}$ In this convivial painting, done a decade after Batoni's portrait and the bust by Hewetson, Wynn has attained the jowls and ample frame foretold by Patch.

Sir Watkin Williams Wynn died in 1789, at the early age of forty. It is said that Mrs. Sheridan (Elizabeth Anne Linley, who married Richard Brinsley Sheridan in 1773) sang to him on his deathbed. ${ }^{23}$

The fate of Sir Watkin Williams Wynn's music collection is unclear, but hints can be gleaned from various sources. Most telling is A. Hyatt King's Some British Collectors of Music c.1600-1960 (Cambridge, 1963), which touches briefly on the collection built up by Wynn and continued by other members of his family. King describes a visit to Wynnstay in 1945, where he saw the remains of the collection in a stable: "a huge mound of music ruined by damp, but splendid even in its mouldering decay . . . Only a fraction of the pile could be rescued, as a pathetic witness to Sir Watkin's breadth of musical interests" (p. 18). His description is of printed music, and the Rutgers MSS, which are in relatively good condition, may have already passed to other hands. This is implied by a list of dispersed collections at the end of King's book, in which that of Sir Watkin Williams Wynn, Bart. is 


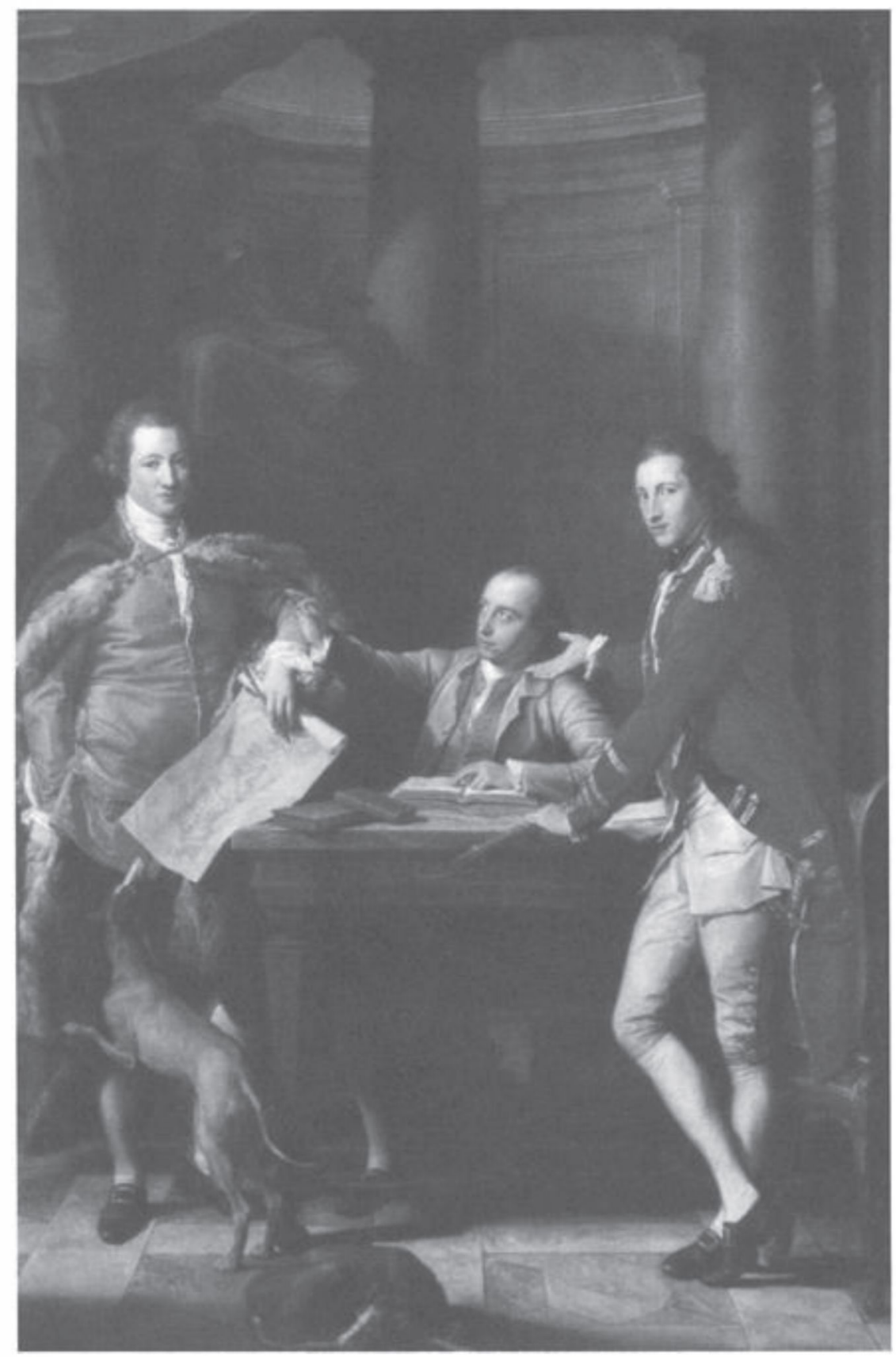

Pl. 1. Pompeo Batoni (1708-1787), Portrait of Sir Watkin Williams Wynn, Bart., Thomas Apperley and Captain Edward Hamilton. Oil on canvas, signed and dated 1768. National Museum of Wales, Cardiff. 

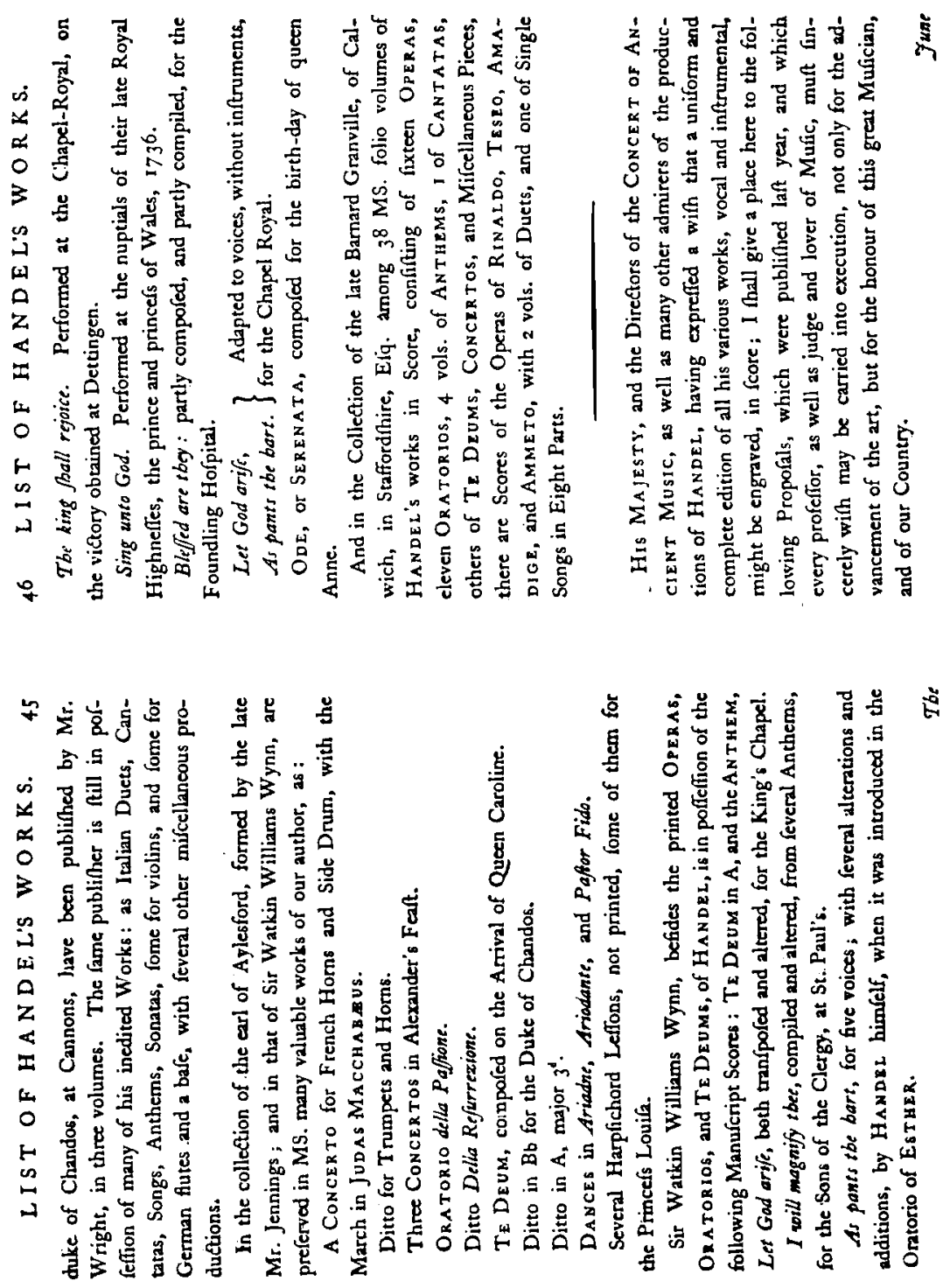

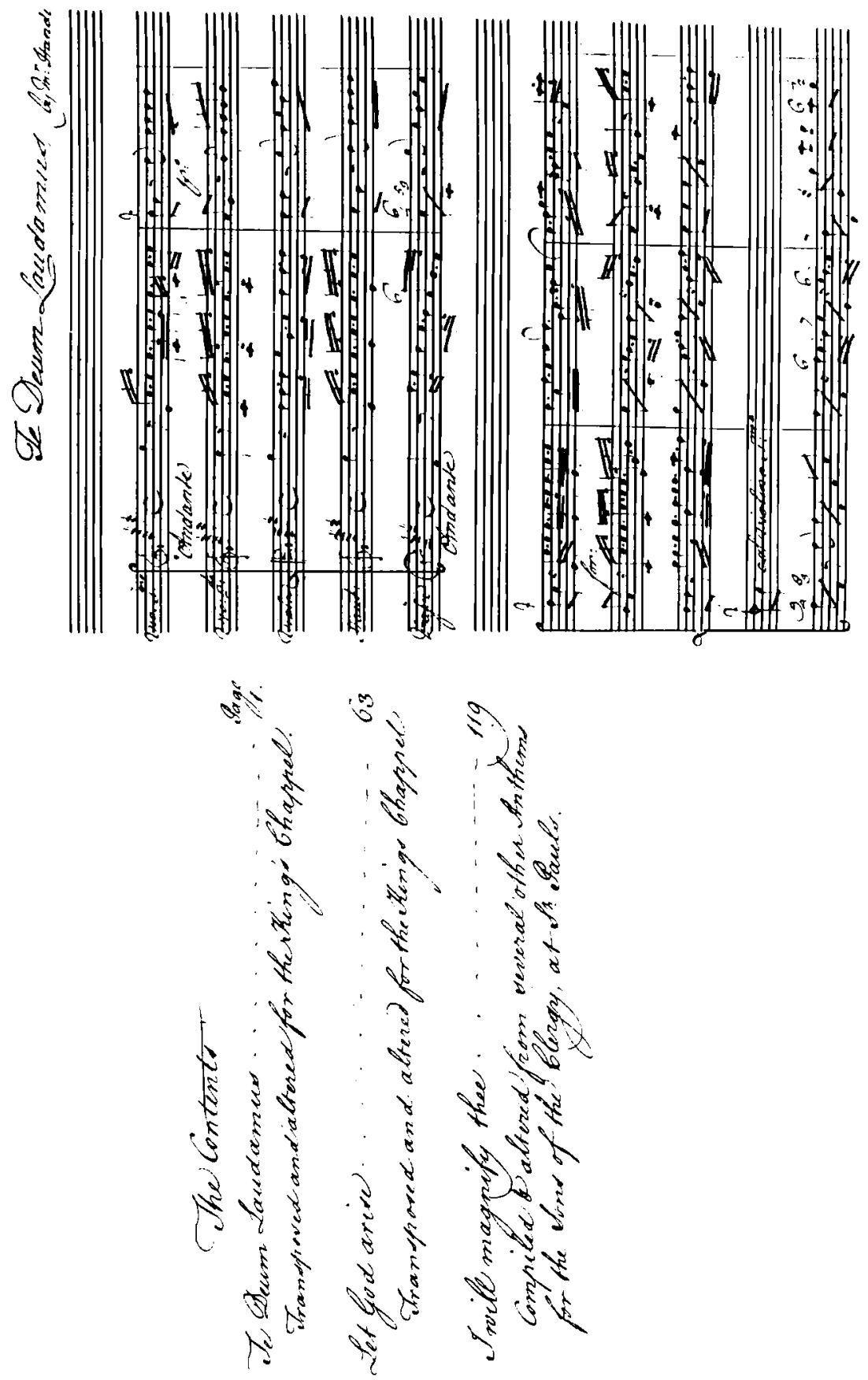

Pl. 3. MS, "Anthems Composed by Mr. Handel, Appendix Vol. I." Rutgers University Libraries, Special Collections and Archives, x Fo. M2038.H14A5, v.2. Table of Contents and p. 1. 


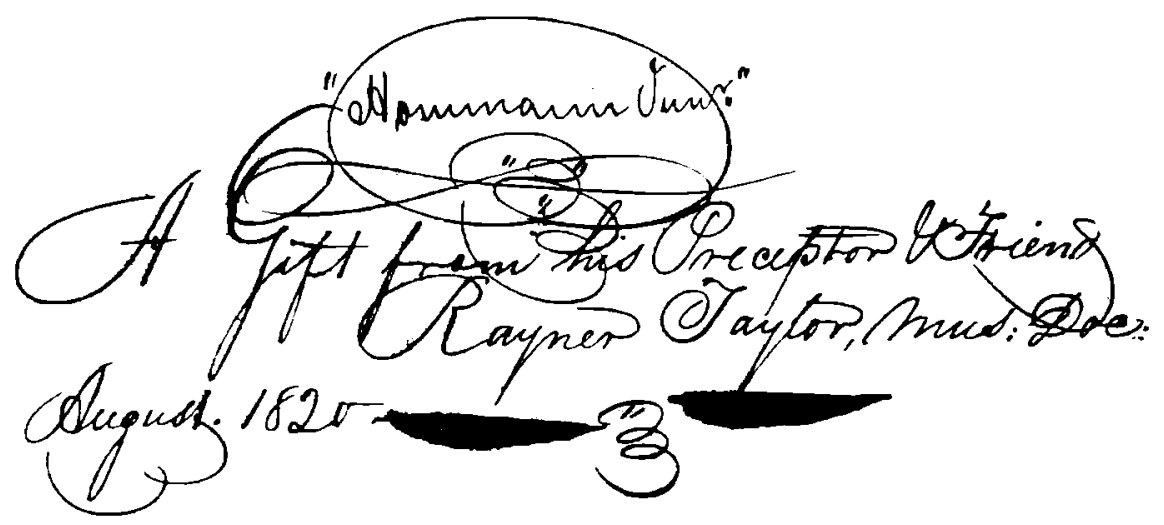

Pl. 4. Flyleaf. Six Concertos For the Harpsicord or Organ Compos'd by Mr. Handel (London, c. 1750). Rutgers University Libraries, Special Collections and Archives, x Fo. M.H236S. Gift of Mrs. Charles C. Hommann, Jr., in memory of Charles C. Hommann, Jr., Class of 1910. 


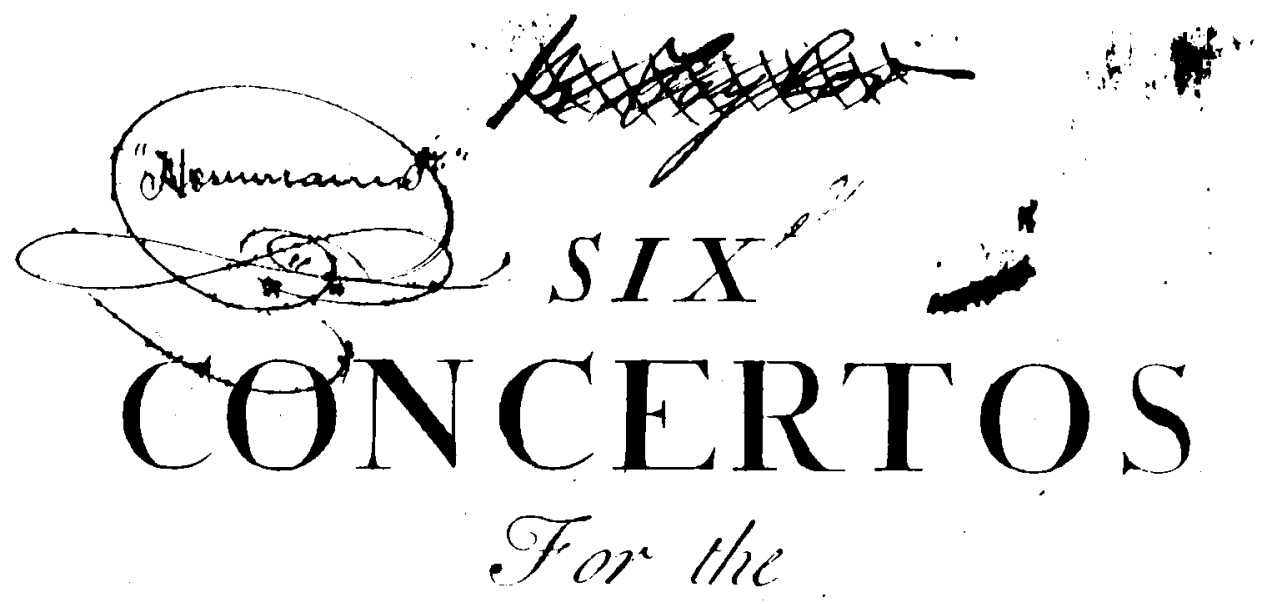

Harplicord or Organ

COMPOS'D BY

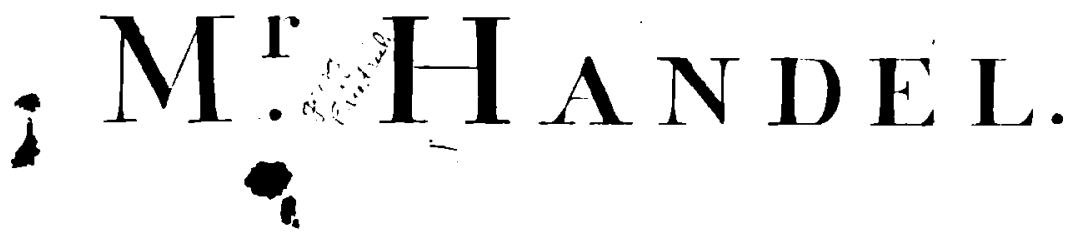

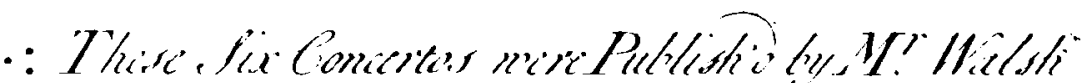
from my onn bopy cineced by my. liff and whim inly I hativien my Righe therein.

London. Prined for I. Walsh in Gatharine foreet in the . Priend.

Of whom may be had

Thr Ir:ftrumental Parts to the ahove six Concertos. fult Piblith'd for the Organ or Harplicord.

Raintalis Cancertos

Rofringravess a Double Fugues, with Srarlatti's CAlthrated J, ifon.

stanleys concertes

Arifinis Comcertus

isugefriv Cancertas
Halfe's Concertos

Handel's Fugues

Roleingrave's is Volumtaries

Zipnli's Voluntaries

Palquinis Volunearies

Hallanis Voluntaries
Albertis I.eltons

Pefcettiv Lellons Handel, I filons I. in illat, Lafloms Harrlei's so Overtirm Henciblive Sous

Pl. 5. Six Concertos Title-page. 
described as having been dispersed in the "early twentieth century" (p. 148).

A few other remnants of Wynn's music collection besides the manuscripts at Rutgers have been traced by Graydon Beeks. ${ }^{24}$ These include unbound volumes of Handel anthems in the collection of Gerald Coke in Hampshire, and a manuscript of Italian cantatas by Handel as well as early editions of his operas at the University of Sydney, Australia. Wynn owned contemporary music too; a manuscript of opera excerpts by Piccini, Monza, and Gassman from his collection is at St. Michael's College, Tenbury. As recently as 1988 a manuscript of Part 2 of Handel's Messiah bearing the Wynn emblem turned up near Manchester. ${ }^{25}$

By whatever means the Handel MSS came to Rutgers, they remain eloquent testimony to Sir Watkin's love of music and collecting. It gives me pleasure to draw the attention of readers of this Journal to their former owner, a distinguished eighteenth-century Welsh collector and patron whose memory is enshrined in the substantial remnant of his library that survives at Rutgers.

\section{Postscript}

One of the Handel volumes at Rutgers (not from the Wynn collection, however) is of special interest for its American associations. This is a printed volume containing Handel's Six Concertos for the Harpsicord or Organ (Op. 4), London: J. Walsh, c.1750, bound with $A$ Second Set of Six Concertos... (1740), once owned by Rayner Taylor (b. London 1747, d. Philadelphia 1825). ${ }^{26}$ Taylor was a choirboy in the Chapel Royal and is said to have been present at Handel's funeral. ${ }^{27}$ As an adult musician he served as organist at Chelmsford and composed for the London stage. In 1792 he emigrated to America, settling in Philadelphia the following year. Active for over three decades in Philadelphia as organist, singer, composer, and teacher, Taylor left a profound mark on American musical life during the Federal period. ${ }^{28}$

The flyleaf of the volume in question bears the inscription "Hommann Junr. A Gift from his Preceptor and Friend Rayner Taylor, Mus. Doc. August, 1820." (Pl. 4) On the title page the name "Mr. Taylor" has been scratched out and "Hommann Jr." written below it. (Pl. 5) The cover of the volume is imprinted "J. C. Hommann Junr." John C. Hommann (senior) was a German musician who immigrated to Philadephia in the 1790s. He had two sons, John Jr. and Charles, the latter of whom was a noted composer and teacher in nineteenth-century Philadelphia (d. after 1862). ${ }^{29}$ 
All three members of the Hommann family were active as violinists in Philadelphia before 1820 and continued to perform in concerts sponsored by the Musical Fund Society after it was founded in that year. The Society's first Directors of Music included Rayner Taylor, Benjamin Carr, and a dozen others, including J. C. Hommann; Hommann Jr. is listed among its members. ${ }^{30}$ The three Hommanns performed at the first concert of the Society (1821), an extraordinary program of symphonies, overtures, concertos, songs, and choruses, including overtures by Rossini and Mehul, and Beethoven's "Grand Sinfonia in C" (probably the First Symphony rather than the Fifth). ${ }^{31}$ The Handel concerto volume (given to Rutgers by Mrs. Charles C. Hommann, Jr., in memory of her husband, Rutgers College class of 1910) thus represents an authentic link between Handel, his distinguished Anglo-American follower Rayner Taylor, and the latter's student J. C. Hommann, Jr., by the generosity of whose family the volume was eventually given to the Rutgers Library.

* This essay is respectfully dedicated to Professor Sir David G.T. Williams, President of Wolfson College, Cambridge, and Vice Chancellor of the University of Cambridge.

\section{Notes}

1 "Handeliana in the Rutgers University Library," in The Journal of the Rutgers University Library, 29 (1965): 3-12.

2 The call number of the nine MS volumes in the Rutgers collection is X Fo. M2038.H14A5. v. 1 (-9).

3 The call numbers of these volumes are X Fo. M1510.H14033 and X Fo. M1529.H14I8, respectively.

${ }^{4}$ Jens Peter Larsen, Handel's Messiah, 2nd ed. (New York, 1972), pp. 326-27; Winton Dean and Anthony Hicks, "Handel," in The New Grove Dictionary of Music and Musicians, ed. Stanley Sadie (London, 1980), 8:83-140; Graydon F. Beeks, "The Chandos Anthems and Te Deum of George Frideric Handel (1685-1759)," (Ph.D. diss., University of California at Berkeley, 1981), pp. 253-73; idem, "Handel's Chandos Anthems: The 'Extra' Movements," Musical Times, 119 (1978): 621-23; idem, "Handel's Chandos Anthems: More 'Extra' Movements," Music \& Letters, 62 (1981): 155-61; Bernd Baselt, HändelHandbuch, Bd. 2, Thematisch-systematisches Verzeichnis: Oratorisch Werke, Vokale Kammermusik, Kirchenmusik (Kassel, 1984), pp. 440ff, 605ff, 680ff; Hallische Händel-Ausgabe, Ser. III, Bd. 4-6, Anthems für Cannons I-III, ed. Gerald Hendrie (Kassel, 1985- ).

For reference purposes, it will be useful here to list the contents of the Rutgers MSS according to the numbers assigned in the Baselt Veræeichnis (HWV):

(1) Anthems, vol. I (HWV 281). (2) Anthems, Appendix vol. I (HWV 282, 256b, 250b). (3) Anthems, vol. II (HWV 248, 253). (4) Anthems, vol. III (HWV 249b, 251b). (5) 
Anthems, vol. V (HWV 250a, 252). (6) Anthems, vol. VI (HWV 251c, 254). (7) Anthems, vol. VII (HWV 265, 263). (8) Anthems, vol. VIII (HWV 268). (9) Anthems, vol. IX (HWV 256a, 251a). (10) An Ode for Queen Anne's Birth-Day (HWV 74). (11) Italian Duettos and Trios (HWV 178, 180, 183-85, 188, 191, 193, 194, 196-201).

${ }^{5}$ Charles Burney, An Account of the Musical Performances . . (London, 1785; reprint, Amsterdam, 1964), part I, pp. 45-46. I have altered the for mat of the original descriptions in order to clarify their relationship to the Rutgers MSS. Originally the sentences describing each work were indented as separate paragraphs. (See P1. 2)

6 "The Chandos Anthems and Te Deum of George Frideric Handel," p. 253, and "Handel's Chandos Anthems: More 'Extra' Movements," p. 157.

7 Music of Eight Centuries. Musical Documents c.1000-c.1800. September 23 through December 14, 1990. Gallery 50, Special Collections and Archives, Alexander Library. The Handel MSS are no. 31 in the catalogue, which contains a facsimile of the opening page of the Birthday Ode.

${ }^{8}$ E.G. Jones, "Wynn family of Wynnstay, Ruabon," in The Dictionary of Welsh Biography down to 1940, ed. J.E. Lloyd and R.T. Jenkins (London, 1959), p. 1100.

9 Charles Mackeson, "Ancient Concerts," Grove's Dictionary of Music and Musicians, 2nd ed., ed. by J.A. Fuller-Maitland (London, 1904, 1:81-82; reprinted in subsequent eds. including 5th ed., ed. by Eric Blom (London, 1954), 1:144-45; Burney, An Account of the Musical Performances, Commemoration, pp. 3, 17.

10 Brinsley Ford, "Sir Watkin Williams-Wynn, A Welsh Maecenas," Apollo, 99 (June, 1974): 435-39, offers an illustrated survey of Wynn's patronage of art and artists.

11 R.D. Griffith, "Parry, John ('The Blind Harpist')", The Dictionary of Welsh Biography, p. 735; Owain Edwards, "Parry, John (i)," The New Grove, 14:245.

12 The statement that Parry is said to have been admired by Handel is made in the article by W.H. Husk, "Parry, John," in Grove's Dictionary of Music and Musicians, 2nd ed., ed. J.A. Fuller-Maitland (London, 1904), 3:627, and subsequent editions. The same statement is found in the revised article by Peter Crossley-Holland in the 5th ed. (1954), $6: 565 f$.

${ }^{13}$ London Daily Post, 27 February 1741; cited in Otto Erich Deutsch, Handel, A Documentary Biography (London, 1955), p. 512.

14 Edwards, "Parry," in The New Grove, 14:245.

15 Percy A. Scholes, The Great Dr. Burney (London, 1948), 1:262.

16 The painting, purchased at the Wynn sale at Sotheby's in 1947 by William Randolph Hearst and given by him to the Los Angeles County Museum, is reproduced and its background described by Nicholas Penny in the splendid Reynolds catalogue of the Royal Academy of Arts (London, 1980), pp. 266-68. Also to be seen there is a photograph of the Music Room of the Wynn house on St. James Square. Penny describes Wynn as "probably 
the most munificent patron of music and painting in Britain in the last twenty years of his life."

17 See Ford, "Sir Watkin Williams-Wynn," pp. 435-36. Although dated 1768, the painting was not completed until 1772. It is now in the National Museum of Wales, Cardiff, having been purchased at the Wynn sale in 1947.

18 See Anthony M. Clark, Pompeo Batoni, A Complete Catalogue of his Works with an Introductory Text (Oxford, 1985), pp. 323-25 and plate 316; and Steve Race, Music with Paintings from the art galleries of the National Museum of Wales (Cardiff, 1980), side 2, bands 1-2 (record and book).

19 Ford, "Sir Watkin Williams-Wynn," pp. 435 (fig. 1), 436.

20 Ford, pp. 435, 437 (fig. 5).

21 Peter Hughes, "Paul Sandby and Sir Watkin Williams-Wynn," The Burlington Magazine, 114 (July 1972): 459-66; the drawing of Wynn appears on p. 461, fig. 21.

22 Ford, p. 439 (fig. 7); Penny, Reynolds, pp. 138 (fig. 109), 281-82; Ellis Waterhouse, Reynolds (London, 1973), p. 29 and plate 81.

23 Ford, p. 439. Reynolds painted a portrait of Mrs. Sheridan as St. Cecilia seated at the organ; see Penny, Reynolds, pp. 265-66 (fig. 94). Burney expressed his admiration for Mrs. Sheridan, calling her "an exquisite and darling singer" (Account, part I, p. 24n).

24 "The Chandos Anthems and Te Deum of George Frideric Handel," pp. 253-55.

25 Donald Burrows, "Newly-recovered Messiah Scores," Newsletter of The American Handel Society, 4/3 (Dec., 1989): 1-5.

26 The volume is described in Picker, "Handeliana," p. 2, with the call number $\mathrm{x}$ Fo. M.H236S. That article, however, does not mention the inscription on the flyleaf identifying the volume as having been given as a gift by "Rayner Taylor, Mus. Doc." in August 1820. The complete inscription is quoted in my exhibition catalogue, Music of Eight Centuries, no. 46, and in the next paragraph of the present article.

A thorough, well-documented biography of Taylor is given in an article by Victor Fell Yellin, "Rayner Taylor," American Music 1 (No. 3, Fall 1983): 48-71. Yellin establishes the correct spelling of Taylor's first name as "Rayner," not "Raynor," the spelling that most reference works give. The inscription in Rutgers's Handel volume also has "Rayner," probably in his own hand.

27 An oft-repeated anecdote, supposedly told by Taylor himself, is that his hat accidentally fell into Handel's grave and was buried with the remains of the great composer. See Louis C. Madeira, Annals of Music in Philadelphia and History of the Musical Fund Society, ed. Philip H. Goepp (Philadelphia, 1896; reprinted New York, 1973), p. 52.

28 In addition to writing the article cited above, Yellin summarizes Taylor's biography in a brief article, "Taylor, Rayner," The Nere Grove Dictionary of American Music, ed. H. Wiley Hitchcock and Stanley Sadie (London, 1986), 4:358. Valuable information dating from Taylor's lifetime is contained in John Rowe Parker, A Musical Biography: or, Sketches of the 
Lives and Writings of Eminent Musical Characters (Boston, 1825; reprint Detroit, 1975, with a new introduction by Frederick Freedman), pp. 179-82 ("Rayner Taylor").

${ }^{29}$ See Karl Kroeger and Richard Claypool, "Hommann, Charles," The New Grove Dictionary of American Music, 2:416.

30 Madeira, Annals, p. 60.

${ }^{31}$ Madeira, pp. 70-76. 